\title{
A STRANGE OCCURRENCE OF PLECTORHINCHUS GATERINUS (ACTINOPTERYGII: PERCIFORMES: HAEMULIDAE) IN THE THRACIAN SEA (EASTERN MEDITERRANEAN)
}

\author{
Maria CORSINI-FOKA ${ }^{1 *}$ and Nikos SARLIS ${ }^{2}$ \\ ${ }^{1}$ Hellenic Centre for Marine Research, Institute of Oceanography, Hydrobiological Station of Rhodes, Greece \\ ${ }^{2}$ Ethnarchou Makariou 35, 85100 Rhodes, Greece
}

Corsini-Foka M., Sarlis N. 2016. A strange occurrence of Plectorhinchus gaterinus (Actinopterygii: Perciformes: Haemulidae) in the Thracian Sea (eastern Mediterranean). Acta Ichthyol. Piscat. 46 (1): 37-41.

\begin{abstract}
A juvenile specimen of Plectorhinchus gaterinus (Forsskål, 1775), a fish native to the western Indian Ocean, was found in the stomach of a squid caught in the shallow waters of the Thracian Sea (northern Aegean Sea). Apart from the occurrence of the species which is reported for the first time in the Mediterranean, this case is rather interesting but should be considered with some reservation for two reasons: the unusual detection of the species of $10 \mathrm{~cm}$ as a prey item of a medium sized cephalopod, and the place of its detection i.e., a marine region that is considered quite inhospitable to alien fish native to tropical environment.
\end{abstract}

Keywords: alien fish, first record, Aegean Sea, introduction pathway/vector

The number of alien fish in the Hellenic Aegean waters accounts for 35 species, after subtracting from previous inventories the species that extended their distribution range unaided from the Atlantic via Gibraltar (Zenetos et al. 2012) and after the addition of recently recorded species, namely Champsodon nudivittis (Ogilby, 1895) (see Corsini-Foka et al. 2015); Terapon theraps Cuvier, 1829 (see Minos et al. 2012); Bregmaceros atlanticus Goode et Bean, 1886 (see Dogrammatzi and Karachle 2015); Pterois miles (Bennett, 1828) (see Corsini-Foka and Kondylatos 2015); and Scarus ghobban Forsskål, 1775 and Oxyurichthys petersii (Klunzinger, 1871) (see Karachle et al. 2016). In the northernmost sector of the Hellenic Aegean waters four alien fish, namely Fistularia commersonii Rüppell, 1838; Lagocephalus sceleratus (Gmelin, 1789); Liza haematocheila (Temminck et Schlegel, 1845); and T. theraps, have been recorded - a number significantly lower compared to the 30 alien fish reported from the southern Hellenic Aegean waters (Corsini-Foka et al. 2015, CorsiniFoka and Kondylatos, 2015). Only the Lessepsian blue cornetfish, F. commersonii, and the silver-cheeked toadfish, L. sceleratus, overlap with the alien fish list from the southern basin, but their establishment is still under discussion, indicating that the environmental conditions at the northern extremity of the basin are quite unfavourable to fish of tropical origin.

In the Mediterranean Sea, the family Haemulidae includes four species, the native Parapristipoma octolineatum (Valenciennes, 1833); Plectorhinchus mediterraneus (Guichenot, 1850); Pomadasys incisus (Bowdich, 1825); and the Lessepsian immigrant Pomadasys stridens (Forsskål, 1775) (see Froese and Pauly 2015).

The first record of Plectorhinchus gaterinus (Forsskål, 1775) in the Mediterranean Sea is reported here with a reservation and its presence in the Thracian Sea (North Aegean) is discussed.

A small fish, preserved frozen, was deposited for identification at the Hydrobiological Station of Rhodes (Hellenic Centre for Marine Research) on 25 June 2015 (Catalogue number HSR118). The sample was found while emptying and cleaning the stomach of a specimen of the European squid, Loligo vulgaris (mantle length of approximately $30 \mathrm{~cm}$ ), captured by one of the authors (NS) on 15 May 2015. The squid was caught with a spear gun at 8-10 $\mathrm{m}$ of depth, on pebbly bottom, in the Thracian Sea, North Aegean, at the northern coast of Thasopoula, an islet at $2 \mathrm{~km}$ from the small city of Keramoti and at 5 $\mathrm{km}$ from the northern coast of Thasos Island (approximate coordinates: $40^{\circ} 49^{\prime} 55^{\prime \prime} \mathrm{N}, 24^{\circ} 42^{\prime} 07^{\prime \prime} \mathrm{E}$; Fig. 1). The approximate surface seawater temperature was about 17$18^{\circ} \mathrm{C}$ and the salinity ranged from $34 \%$ to $35 \%$.

Morphometric measurements were taken with a digital calliper under a stereoscope. The identification of the specimen was carried out following McKay (1984) and Smith and McKay (1986). Publications of Ben-Tuvia and McKay (1986), Louisy (2002) and Froese and Pauly (2015) were also consulted.

The juvenile specimen, $105.9 \mathrm{~mm}$ of total length, was in good status of conservation and did not show signs of 
digestion (Fig. 2), though leading to the conclusion that the fish was very recently captured and swallowed by the squid. Description. Dorsal fin rays: XIII +19 ; Anal fin rays: III +7 (second spine strong and longer than third); Pectoral fin rays: 15; Pelvic fin rays: $I+5$. Chin with 6 pores not followed by median groove. Gill rakers of first arch: 18 on lower limb, 1 at corner, and 8 on upper limb. Preopercle with 22 spines. Mouth reaching anterior margin of eye, but not overpassing it. Scales ctenoid, rough to touch and extending to nostrils. Palate red-orange. Caudal fin truncate. Selected proportions: head length 29.28 , body depth 35.31 as \% of standard length, eye diameter 32.26 , interorbital distance 22.58 , snout length 35.03 all as \% of head length (Table 1). Colour of defrosted specimen. Pale silver-grey with six dark, longitudinal bands (from above, first four black, the fifth paler greyish and last, ventral shorter and vanishing) (Fig. 2), bending downward and converging to snout (Fig.
2, detail). Pectoral fins yellowish transparent, pelvic fins yellowish with dark shadings, anal fin yellowish with more intense dark shadings. Dorsal fin yellowish, whole upper margin blackish, black band at base of spinous dorsal fin and first third of soft dorsal fin, continuing horizontally in middle of the remaining soft dorsal fin (Fig. 2). Caudal fin with evident dark band crossing transversally upper lobe and dark large blotches in rest of fin.

Characteristics and coloration of the young specimen were fully consistent with the specimens of Plectorhinchus gaterinus (Forsskål, 1775) (Haemulidae) described in McKay (1984), Smith and McKay (1986), and Froese and Pauly (2015), apart from the pelvic fins length, being, in the presently reported specimen, only slightly longer than pectoral fins (Table 1).

Similarly to its confamiliar species, adults of Plectorhinchus gaterinus differ in colour compared to

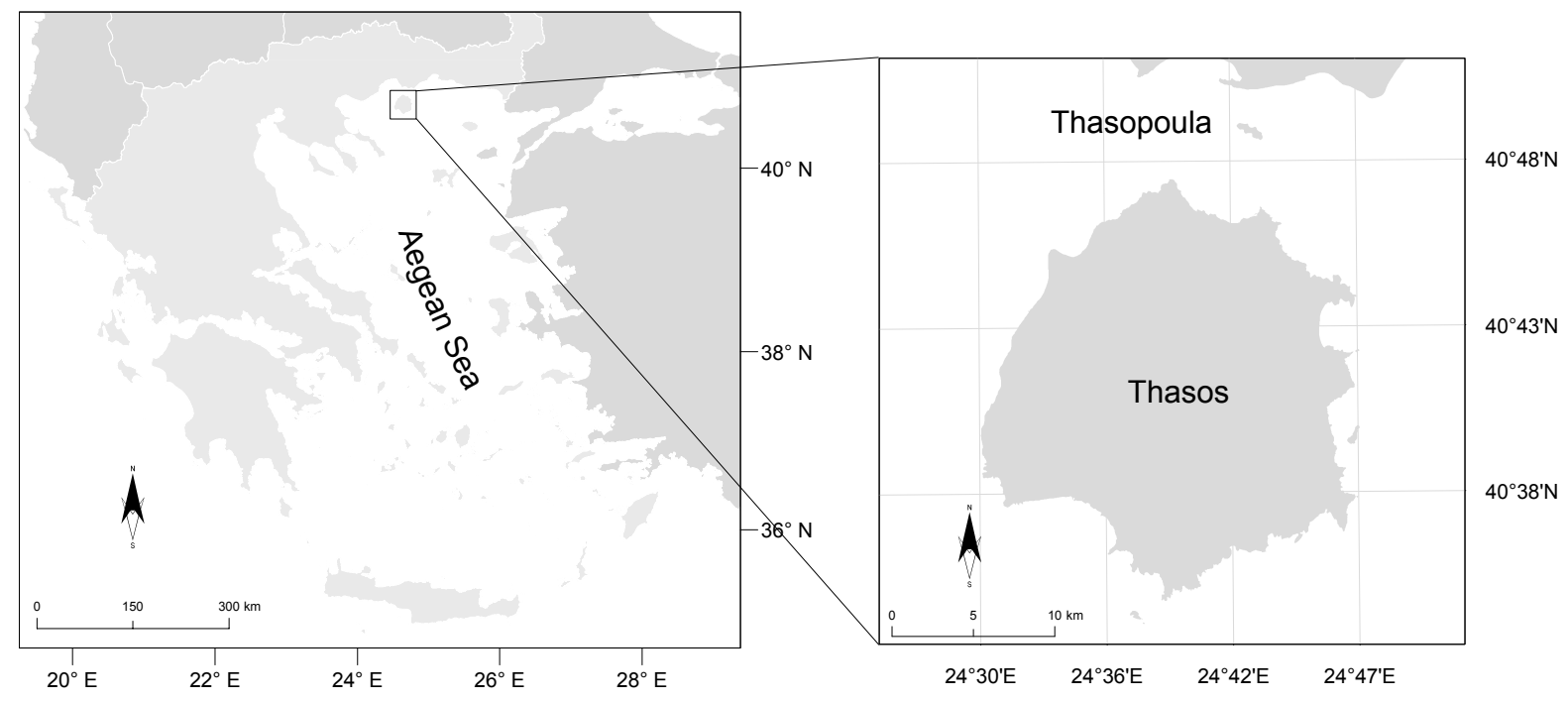

Fig. 1. Map of the Aegean Sea and Loligo vulgaris-Plectorhinchus gaterinus sampling location, North to Thasos Island, Thracian Sea (right)
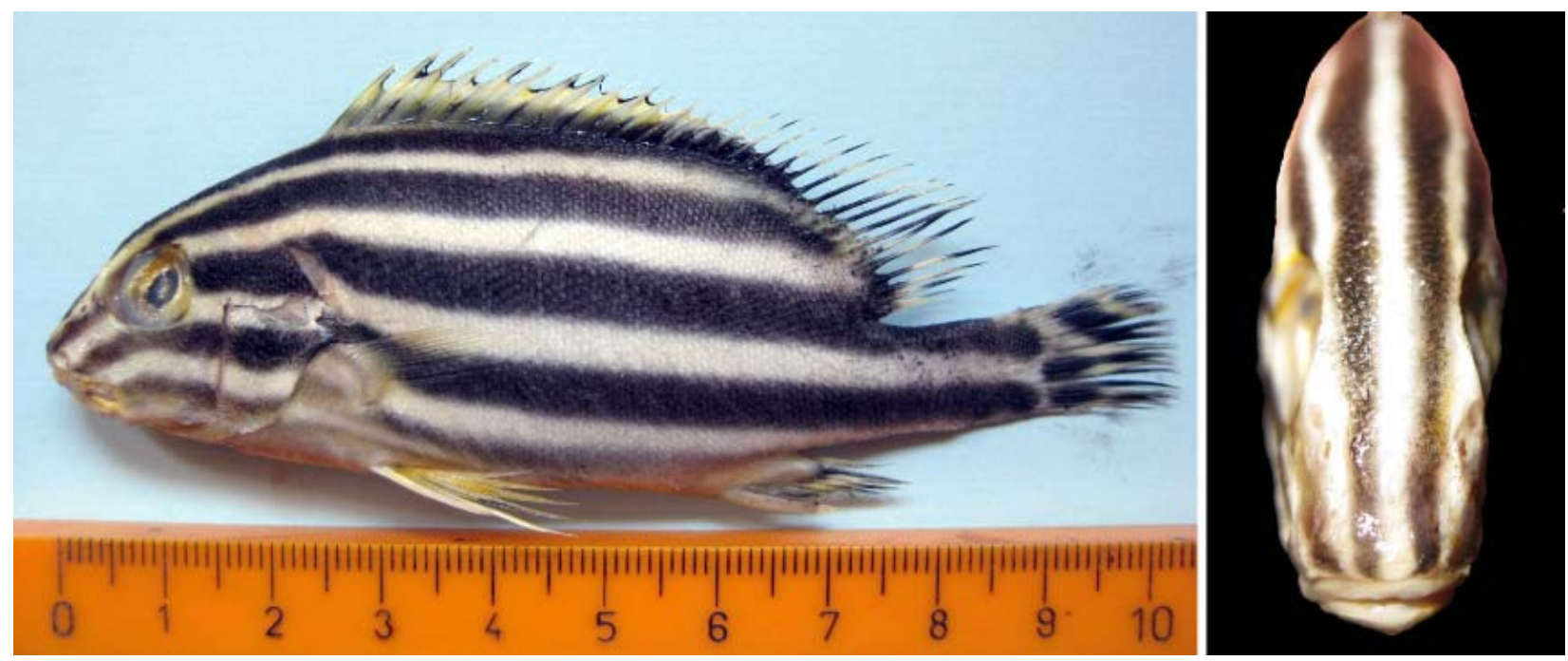

Fig. 2. The specimen of Plectorhinchus gaterinus (total length $105.9 \mathrm{~mm}$ ), found in the stomach of the squid Loligo vulgaris, in the Thracian Sea (Detail: frontal view, showing the trend of dark bands on snout) 
juveniles. Adults are yellowish grey, back greenish, and belly yellowish, while the black stripes bands of juveniles break into lines of dark grey or black-brown spots on body and fins at $10-12 \mathrm{~cm}$ of standard length (thus, the common name blackspotted rubberlip) (McKay 1984).

Up to date, only one species congeneric to Plectorhinchus gaterinus is known in the Mediterranean Sea, namely the native Plectorhinchus mediterraneus, from which our sample differs in meristic counts and colour pattern. Following Ben-Tuvia and McKay (1986), gill rakers of $P$. mediterraneus are 19-20 on lower arch, dorsal fin is XI-XII + 17-19 and anal fin III + 8-9 (gill rakers 18 on lower arch, dorsal fin XIII +19 , and anal fin III +7 , respectively in our sample), while, according to Louisy (2002) juveniles of $P$. mediterraneus have two longitudinal stripes (six in our sample).

The distribution range of Plectorhinchus gaterinus is the Western Indian Ocean: Red Sea, Gulf of Aqaba, Gulf of Aden, Persian Gulf, south to Natal, South Africa, Mauritius, Madagascar, Comoro and Reunion Islands (McKay 1984, Froese and Pauly 2015). It occurs at 5-55 $m$ of depth in coastal reefs, sand banks and near estuaries, often in large groups under ledges or along coral slopes by day (Froese and Pauly 2015). The common size of the Blackspotted rubberlip is $35 \mathrm{~cm}$ in length, up to $45-50 \mathrm{~cm}$. It feeds mainly on crustaceans, molluscs, small benthic organisms, and small fishes. In underwater surveys, it is approached with relative ease. The species is fished commercially by hand-lines, gillnets, traps, and spears, but its flesh is not greatly esteemed due to its iodoform taste (Smith and McKay 1986).

Small juveniles of Plectorhinchus gaterinus are seen in the aquarium trade, being attractive for their dazzling coloration and the interesting, exaggerated, side-to-side swimming motion, but they usually suffer as they are finicky eaters. Keeping of $P$. gaterinus in captivity is suggested only for advanced aquarists, at temperatures between $22^{\circ} \mathrm{C}$ and $28^{\circ} \mathrm{C}$, in large tanks

Table 1

Principal morphometric measurements of Plectorhinchus gaterinus specimen from the Thracian Sea (northern Aegean)

\begin{tabular}{lc}
\hline \multicolumn{1}{c}{ Parameter } & Value $[\mathrm{mm}]$ \\
\hline Total length & 105.90 \\
Standard length & 91.36 \\
Head length & 26.75 \\
Eye diameter & 8.63 \\
Interorbital distance & 6.04 \\
Body depth & 32.26 \\
Pectoral fin length & 18.55 \\
Pelvic fin length & 21.37 \\
SoDFB length & 24.77 \\
SpDFB Length & 31.53 \\
Snout length & 9.37 \\
Caudal peduncle depth & 10.07 \\
Upper jaw length & 9.02 \\
\hline
\end{tabular}

$\mathrm{SoDFB}=$ soft dorsal fin basis, $\mathrm{SpDFB}=$ spinous dorsal fin basis. of 700-1000 L capacity, adequate to house the adults. This species is therefore suitable for large tropical displays of public aquaria, such as the Aquarium of the Oceanographic Museum of Monaco (Pierre Gilles, personal communication) and the Aquarium La Rochelle, France (Pierre Moriniere, personal communication); in the past, it was kept also at the Wilhelma ZoologischBotanischer Garten Stuttgart, Germany (Isabelle Koch, personal communication).

At this stage of knowledge, the pathway/vector of introduction of Plectorhinchus gaterinus in the Thracian Sea is unknown. A possible introduction of the species through the Lessepsian migration process seems, at the moment, unlikely because of

The environmental conditions in the marine area under study, as mentioned above, appear unfavourable to the establishment of species of Red Sea/Indo-Pacific origin;

There have been no other records of $P$. gaterinus along the pathway of colonization usually followed by Lessepsian immigrants along the Levantine coasts, after their arrival into the Mediterranean via the Suez Canal.

Some Lessepsian immigrant fish such as Lagocephalus sceleratus and Tylerius spinosissimus (Regan, 1908) were firstly recorded in the Mediterranean basin from the southeastern Aegean Sea (Golani 2010), a region characterized by a subtropical environment suitable for alien biota of Red Sea origin (Corsini-Foka et al. 2015). The possibility that the fish under study was undetected by divers or fishermen seems also improbable: its size is not irrelevant, its typical and evident dark stripes attract attention and do not allow it to be confused with other species, it dwells in shallow coastal waters and it is easily approached.

Plectorhinchus gaterinus is not listed as a pet fish in aquarium stores in Greece (Papavlasopoulou et al. 2014) but today an additional source of ornamental aquatic organisms is the online trade, an emerging commerce, poorly regulated and probably overlooked in many countries (Mazza et al. 2015). The presently reported $P$. gaterinus may be either a very recent juvenile escapee from aquarium trade or accidental release or discard by aquarists (Zenetos et al. 2012). Furthermore, introduction of $P$. gaterinus via a cargo ship in its ballast waters should not be excluded, as hypothesized for Terapon theraps by Minos et al. (2012), after its finding in Chalkidiki waters, Northwest Aegean Sea.

The majority of the newcomers are recorded for the first time in the Mediterranean through fishery activities (professional, amateur, research) or underwater biological surveys. Plectorhinchus gaterinus was firstly detected as a prey item of the European squid, Loligo vulgaris, common in the study area. Although unusual, this case is not unique: Bregmaceros atlanticus was found for the first time in the stomach of a lizardfish, "Saurida undosquamis (Richardson, 1848)" (see Y1lmaz et al. 2004), a Lessepsian immigrant recently described as the new species Saurida lessepsianus Russell, Golani, Tikochinski, 2015.

The modality of the present finding, although it is a single and casual one, could indicate, however, 
that, in addition to the rather adverse environmental characteristics of the northernmost sector of the Aegean Sea when the introduction of exotic fishes is considered, predation performed by native biota may be an efficient natural control factor of newcomers at the initial stage of their possible attempts to adapt to the new ecosystem.

Based on the comments and suggestions of renowned Mediterranean cephalopod experts, the presently reported finding of an intact specimen of Plectorhinchus gaterinus of the length of about $10 \mathrm{~cm}$, in the stomach of a medium sized squid (approximately $30 \mathrm{~cm}$ ) is extraordinary and should be approached with a reservation. However, due to the ongoing changes in marine biodiversity in the Mediterranean, it is believed that every record, despite of how strange it might appear, should be reported for the sake of future scientific findings.

\section{ACKNOWLEDGEMENTS}

Authors greatly thank the members of the European Union of Aquarium Curators (EUAC) for their availability in providing information on keeping Plectorhinchus gaterinus in European public aquaria and, in particular, Pierre Gilles, Aquarium of the Oceanographic Museum of Monaco, Pierre Moriniere, Aquarium La Rochelle, France and Isabelle Koch, Wilhelma Zoologisch-Botanischer Garten Stuttgart, Germany. They also thank Dimitris Poursanidis for providing vector graphic figures and Elias Santorinios for technical support.

Special thanks are due to the malacologists Fabio Crocetta, Eugenia Lefkaditou (HCMR) and Giambattista Bello (Bari), who commented on the remote possibility of finding an intact animal in a squid stomach.

\section{REFERENCES}

Ben-Tuvia A., McKay R. 1986. Haemulidae. Pp. 858-864. In: Whitehead P.J.P., Bauchot M.-L., Hureau J.-C., Nielsen J., Tortonese E. (eds.) Fishes of the north-eastern Atlantic and the Mediterranean. Vol. 2. UNESCO, Paris.

Corsini-Foka M., Kondylatos G. 2015. First occurrence of the invasive lionfish Pterois miles in Greece and the Aegean Sea. P. 692. In: Crocetta F., Agius D., Balistreri P., Bariche M., Bayhan Y.K., Çakir M., Ciriaco S., Corsini-Foka M., Deidun A., El Zrelli R., Ergüden D., Evans J., Ghella M., Giavasi M., Kleitou P., Kondylatos G., Lipej L., Misfud C., Özvarol Y., Pagano A., Portelli P., Poursanidis D., Rabaoui L., Schembri P.J., Taşkin E., Tiralongo F., Zenetos A. 2015. New Mediterranean biodiversity records (October 2015). Mediterranean Marine Sciences 16 (3): 682-702.

DOI: $10.12681 / \mathrm{mms} .1477$

Corsini-Foka M., Zenetos A., Crocetta F., Çinar M.E., Koçak F., Golani D., Katsanevakis S., Tsiamis K., Cook E., Froglia C., Triandaphyllou M., Lakkis S., Kondylatos G., Tricarico E., Zuljevic A., Almeida M., Cardigos F., Çağlar S., Durucan F., Fernandes A.M.D., Ferrario J., Haberle I., Louizidou P., Makris J., Marić M., Micu D., Mifsud C., Nall C., Kytinou E., Poursanidis D., Spigoli D., Stasolla
G., Yapici S., Roy H.E. 2015. Inventory of alien and cryptogenic species of the Dodecanese (Aegean Sea, Greece): Collaboration through COST action training school. Management of Biological Invasions 6 (4): 351-366.

DOI: $10.3391 / \mathrm{mbi} .2015 .6 .4 .04$

Dogrammatzi A., Karachle P.K. 2015 First record of the antenna codlet Bregmaceros atlanticus Goode \& Bean, 1886 in Greek waters. P. 273. In: Zenetos A., Akel E.H.K., Apostolidis C., Bilecenoglu M., Bitar G., Buchet V., Chalari N., Corsini-Foka M., Crocetta F., Dogrammatzi A., Drakulić M., Fanelli G., Giglio G., Imsiridou A., Kapiris K., Karachle P.K., Kavadas S., Kondylatos G., Lefkaditou E., Lipej L., Mavrič B., Minos G., Moussa R., Prato E., PancucciPapadopoulou M.A., Renda W., Ríos N., Rizkalla S.I., Russo F., Servonnat M., Siapatis A., Sperone E., Theodorou J.A., Tiralongo F., Tzovenis I. 2015. New Mediterranean biodiversity records (April 2015). Mediterranean Marine Science 16 (1): 266-284.

DOI: $10.12681 / \mathrm{mms} .1292$

Froese R., Pauly D. (eds.) 2015. FishBase. [Version 06/2015] www.fishbase.org

Golani D. 2010. Colonization of the Mediterranean by Red Sea fishes via the Suez Canal-Lessepsian migration. Pp. 145-188. In: Golani D., AppelbaumGolani B. (eds.) Fish invasions of the Mediterranean Sea: Change and renewal. Pensoft Publishers, SofiaMoscow.

Karachle P.K., Angelidis A., Apostolopoulos G., Ayas D., Ballesteros M., Bonnici C., Brodersen M.M., Castriota L., Chalari N., Cottalorda J.M., Crocetta F., Deidun A., Đođo Ž., Dogrammatzi A., Dulčić J., Fiorentino F., Gönülal O., Harmelin J.G., Insacco G., Izquierdo-Gómez D., Izquierdo-Muñoz A., Joksimović A., Kavadas S., Malaquias M.A.E., Madrenas E., Massi D., Micarelli P., Minchin D., Önal U., Ovalis P., Poursanidis D., Siapatis A., Sperone E., Spinelli A., Stamouli C., Tiralongo F., Tunçer S., Yaglioglu D., Zava B., Zenetos A. 2016. New Mediterranean biodiversity records (March 2016). Mediterranean Marine Science 17 (1): 230-252. DOI: $10.12681 / \mathrm{mms} .1684$

Louisy P. 2002. Guide d'identification des poissons marins: Europe et Méditerranée. Ulmer, Paris.

Mazza G., Aquiloni L., Inghilesi A.F., Giuliani C., Lazzaro L., Ferretti G., Lastrucci L., Foggi B., Tricarico E. 2015. Aliens just a click away: The online aquarium trade in Italy. Management of Biological Invasions 6 (3): 253-261. DOI: $10.3391 / \mathrm{mbi} .2015 .6 .3 .04$

McKay R.J. 1984. Haemulidae. In: Fischer W., Bianchi G. (eds.) FAO species identification sheets for fishery purposes. Western Indian Ocean (Fishing Area 51). Vol. 2. FAO, Rome.

Minos G., Imsiridou A., Economidis P.S. 2012. First record of Terapon theraps (Terapontidae) in the Aegean Sea (Greece). Cybium 36 (2): 401-402. 
Papavlasopoulou I., Vardakas L., Perdikaris C., Zenetos A., Gofas S., Morri C., Rosso A., Violanti Kommatas D., Paschos I. 2014. Ornamental fish in pet stores in Greece: A threat to biodiversity? Mediterranean Marine Science 15 (1): 126-134. DOI: $10.12681 / \mathrm{mms} .484$

Smith M.M., McKay R.J. 1986. Haemulidae. Pp. 564-571. In: Smith M.M., Heemstra P.C. (eds.) Smiths' sea fishes. Springer-Verlag, Berlin.

Yılmaz R., Bilecenoğlu M., Hoşsucu B. 2004. First record of the antenna codlet, Bregmaceros atlanticus Goode \& Bean, 1886 (Osteichthyes: Bregmacerotidae), from the eastern Mediterranean Sea. Zoology in the Middle East 31 (1): 111-112. DOI: $10.1080 / 09397140.2004 .10638031$ D., García Raso J.E., Çinar M.E., Almogi-Labin A., Ates A.S., Azzurro E., Ballesteros E., Bianchi C.N., Bilecenoglu M., Gambi M.C., Giangrande A., Gravili C., Hyams-Kaphzan O., Karachle P.K., Katsanevakis S., Lipej L., Mastrototaro F., Mineur F., Pancucci-Papadopoulou M.A., Ramos Esplá A., Salas C., San Martín G., Sfriso A., Streftaris N., Verlaque M. 2012. Alien species in the Mediterranean Sea by 2012. A contribution to the application of European Union's Marine Strategy Framework Directive (MSFD). Part 2. Introduction trends and pathways. Mediterranean Marine Science 13 (2): 328-352.

DOI: $10.12681 / \mathrm{mms} .327$

Received: 31 August 2015

Accepted: 13 January 2016 Published electronically: 31 March 2016 